\title{
Literature Review on the Urban Environment of Krasnoyarsk
}

\author{
Maya G. Smolina, Natalia P. Koptseva \\ and Ekaterina A. Sertakova* \\ Siberian Federal University \\ 79 Svobodny, Krasnoyarsk, 660041, Russia
}

Received 10.08.2018, received in revised form 26.09.2018, accepted 10.10.2018

An article gives a review of the scientific literature on the urban environment in Krasnoyarsk, defines main areas of research of this topic, provides analysis of representative scientific publications reflecting the fixation of characteristics and describing the dynamic change of the environment. The result was an examination of more than 50 sources, including applied projects and the results of surveys of citizens and experts. The application of the research results is a study within the framework of the RFBR project on urban transformations in Krasnoyarsk since 1990-2010. The author makes a conclusion that modern studies of Krasnoyarsk have been carried out in the following areas: the diagnostics to determine the level of city's ecological state; monitoring public opinion; research on the causes of migration of educated youth, as well as aesthetic criticism of the territory; cataloging the historical, cultural and architectural heritage objects; discussing city planning and the problems of this plan implementation, as well as the problems of the general mobility of citizens, including the accessibility of the urban environment for persons with reduced mobility. Moreover, the article draws attention to the city planning concept of the "garden city" as an embodiment of the synthesis of social, aesthetic and green intentions of society.

Keywords: Krasnoyarsk, Krasnoyarsk urban environment, Krasnoyarsk ecology, Krasnoyarsk Krai nature, Krasnoyarsk architecture, urban planning, urban greening in Krasnoyarsk, Krasnoyarsk roads, Krasnoyarsk youth, migration.

The reported study was funded by Russian Foundation for Basic Research, Government of Krasnoyarsk Krai, Krasnoyarsk Regional Fund of Science within the framework of the research project: "Transformation of Krasnoyarsk urban environment in 1991-2017".

Research area: culturology.

Citation: Smolina, M.G. (2018). Literature review on the urban environment of Krasnoyarsk. J. Sib. Fed. Univ. Humanit. soc. sci., 11(10), 1653-1672. DOI: 10.17516/1997-1370-0326.

(c) Siberian Federal University. All rights reserved

* Corresponding author E-mail address: smomg@yandex.ru

This work is licensed under a Creative Commons Attribution-NonCommercial 4.0 International License (CC BY-NC 4.0). 


\section{Introduction}

The purpose of this article is to review studies related to the urban environment of Krasnoyarsk within the project of transforming the urban space of Krasnoyarsk from 1991 to this day. The present review implies classification of existing studies on different aspects of the urban environment. It turned out that there are three interrelated aspects in the studies devoted to the Krasnoyarsk urban environment. These are 1. ecological, 2. historical and architectural, 3. social and cultural aspects.

It was necessary to single out these aspects in sundry scientific publications covering this problematics, since they are not equal to the factors influencing the environment. Factors influencing the environment are anthropogenic, biotic and abiotic ones, while the research aspects focus not on the genesis of the problem, but rather on its essence (the question of interaction between the cultural and natural characteristics in Krasnoyarsk, the challenge of changing its historical and architectural appearance, the problem of cultural attitudes of society to the city). It is worth considering these aspects in more detail and highlight key trends in the related scientific articles.

First and foremost I shall name the philosophical studies connected with urban anthropology and its methodological possibilities. The researchers here include M.I. Bukova (2017), A.V. Kistova (2017), M.I. Ilbeykina, M.A. Kolesnik, N.M. Libakova, E.A. Sertakova, A.A. Sitnikova (2015), E.A. Sertakova (2018).

Next, let us consider specific scientific areas in Krasnoyarsk studies.

1. Ecological problems of the urban environment

Most of the research on the Krasnoyarsk urban environment is devoted to the ecological state, city's biometric evaluation made via using different plants as indicators. How do these plants undergo close connection with man and how can they show a degree of the environment pollution? L.N. Suntsova, E.M. Inshakov, E.V. Kozik from Krasnoyarsk Siberian State University of Technology put forward silver birch (Betula pendula) as an effective bioindicator for assessing the urban environment (2011). This is also proved by the research of the scientists from Krasnoyarsk Agrarian University E.V. Avdeeva, V.F. Nademyanov (2013), who studied the leaf lamina of silver birch in Krasnoyarsk squares, which led them to the conclusion that it is impossible to change for the better the level of man-made impact with the help of increasing the density of squares and their size.

The team of researchers from Siberian Federal University - E.P. Chernykh, G.G. Pervyshina, O.V. Gogoleva, having chosen the bird cherry (Prunus Padus) as a bioindicator, rated the city districts by their ecological conditions as a result of their 
research. The most environmentally friendly area is Akademgorodok, while the last place belongs to the territory of UC Rusal (2014). Researchers V.I. Polonskii, I.S. Poliakova showed that the Hungarian lilac (Syringa josikaea) as an indicator is even more effective than the silver birch (2014). In particular, thanks to this indicator, the authors manage to prove that the Vetluzhanka microdistrict in Krasnoyarsk is also environmentally friendly (yielding the palm to Akademgorodok). Another team of authors - A.S. Dontsov, L.N. Suntsova, E.M. Inshakov (2016) calculated the degree of pollution in the Krasnoyarsk districts using such a bioindicator as Siberian spruce.

Assessment and analysis of inhalation risk and air quality standards in the region were carried out by O.V. Taseiko, S.V. Mikhailiuta, A.A. Lezhenin (2013), O.V. Taseiko, E.N. Leonova, T.P. Spitsyna, (2013), A.A. Golubnichii, E.A. Chaikina (2015), and according to their findings, the deterioration of the ecological situation in the city has been worsened by formaldehyde, the concentration of which in the city atmosphere has been unexceptionally high for 10 years. The other side of risk is connected with the way of life of citizens, when they spend most of their time indoor, while industrial waste is often used for the production of modern building materials, so that long exposure to confined spaces is dangerous.

According to S.N. Bobylev, O.V. Kudriavtseva, S.V. Solov'eva, (2014), in Russia there are 138 cities with high and very high levels of pollution, and Krasnoyarsk is one of them.

E.V. Avdeeva, A.A. Karelina in their article (2017) describe the role of the water resource - the Yenisei River in the Krasnoyarsk urban environment. Researchers write that in Krasnoyarsk, the Yenisei River flows from west to east, the prevailing bed width is $500-600 \mathrm{~m}$ (with maximum width of $700 \mathrm{~m}$ and minimum $-300 \mathrm{~m}$ ), the depth in some places reaches $6 \mathrm{~m}$, the riverbed is branched by islands into channels. The largest islands in the city are these islands: Otdykha, Molokova, Tatyshev, Atamanovsky. The river has been intensively used for many decades as a transport artery, for supplying water to numerous cities and towns, for fishing and recreational purposes. Systematic observations of surface water pollution in Krasnoyarsk Krai have been carried out at the hydrochemical network control points. Stations use different indicators most characteristic for each waterbody. It is concluded that the main sources of waterbodies pollution are wastewater from various types of industries, farms, housing and communal utilities, surface runoff and river transport. The article presents the dynamics of the Yenisei River pollution over an 18-year period under the influence of technogenic environmental factors in Krasnoyarsk, as well authors name 
the main sources and chemical substances contributing to the waterbody pollution, including those exceeding the maximum permissible concentrations. According to the researchers, the water areas should be the main and secondary axes on which the most important elements of the city's natural structure are to be based.

E.V. Avdeeva, V.F. Poletaikin, E.A. Vagner in their article (2015) examine the relationship of the natural environment, the skeleton structure and the greening system of the industrial centre of Siberia - Krasnoyarsk in the historical aspect and describe specifics of its development. In the course of their study they identified five main stages in the development of the city's spatial basic structure and its influence on the formation of greening system: from a fortress with a trading settlement (posad) outside its walls, practically without any plantation, to the large city with a developed and discrete plan structure and a specially designed system of greening, which includes the whole complex of landscaping objects (for public and limited use and special purposes). It is well-known that during its formation the city was located in particularly comfortable microclimatic conditions of the intermontane basin protected from the northern winds, and the compactness of the fortress and posad was in line with specific climatic conditions and the natural environment. Currently, adverse combinations of factors for the city are the pit and ditch formation of the mountain relief, ground inversions and no wind weather conditions in the location of industrial enterprises situated higher in relation to the residential areas of the city. The urban environment is created on the basis of landscape resources, which are the basis for the man-made objects and serve as the foundation for the construction of the greening system. Landscape resources determine the spread and productivity of vegetation in the city plantations. The degree of correspondence of the terrain's bioclimatic resources to the ecological niches of woody plants makes it possible to use the types of trees and shrubs most adapted to local landscape conditions in city urban greening. Thus, present situation in the environmental assessment demonstrates certain disadvantages which society is interested in making up.

\section{Historical and architectural originality}

In the article by Krasnoyarsk scientist V.I. Kruslinskii "The problems of the interaction between natural and urban systems" (Krushlinskii, 2016) one can find a story of the design and development of Krasnoyarsk as a garden city in the 1980s and an account of the clash with the realities of the construction business in the last decades. The article is especially descriptive thanks to conceptual-visual diagrams, representing the complexity of the relationship between nature and the urban environment. 
Among the studies on the historical appearance of the Krasnoyarsk urban environment, I can distinguish the work by O.V. Antonenko (2013), in which he finds that the main starting point of the city's architectural problems is the 1990s, which is connected with the endless infill construction with numerous office buildings and blocks of flats that were aesthetically different from each other and did not make a single whole, which in turn resulted in overloading the city centre with shopping and entertainment malls. Listing the consequences, the author points out problems with the city infrastructure and deterioration of the ecological situation. Describing the advantages of the Krasnoyarsk urban environment, the author mentions high left bank of the Yenisei river, which makes the city a beautiful wooded place. As for the right bank, the researcher alludes to the fact that there is a lack of convenient sites for construction here, therefore, mainly high-rise development is being carried out. In conditions of the city linear development along the river bank and because of its complex relief, the city planners constantly search for ways of updating the city plan. A particular task is the improvement of the riverine territory.

V.I. Krushlinskii, O.S. Fedorova in their article (2016) present the results of research and analysis of the Krasnoyarsk territory. With the help of a sociological survey of experts and citizens, the authors identified attractive and comfortable places in the city, eye-catching and memorable architectural objects both of modern era and with long history. They also specify disharmonic elements which must be neutralized and bring forward the principles for the introduction of new forms into the project of new centre and its reconstruction. For this they identified distinctive and common features of the existing architectural appearance, studied the peculiarities of the influence of complex natural and climatic factors on city planning and architecture, the creation of a concept, principles and techniques for designing new ensembles and forms matching with existing buildings, as well as with the landscape, its dominants, other natural conditions. The researchers examined examples of the real projects of the Krasnoyarsk new centre made by such architecture institutes as "KrasnoyarskNIIproekt" and "KrasnoyarskGrazhdanproekt". The analysis of the decisions on the new centre takes into account the aesthetic characteristics of the Krasnoyarsk's natural environment.

Historical and cultural heritage of the Soviet era in the city's architectural environment is estimated in an article by N.I. Grekov (2014). The author believes that the preserved old buildings of the 1930s-1950s set the originality of the city. For example, in Oktyabrsky District these streets include Novaya Zarya Str., Bauman Str., Novosibirskaya Str., part of Svobodny Prospect, in addition, there are similar houses 
in each Krasnoyarsk district. The population of such areas, as a rule, is made up by social stratum having low incomes with overwhelming share of elderly citizens. Old, dilapidated communications do not add to the appeal of old houses. Run-down premises, being obsolete morally and physically, nevertheless, retained a significant margin of strength of structures. Thus, the author refers to the contradiction between the existing historical and architectural fund of Stalin's epoch and the lack of care for their preservation.

A.V. Slabukha considers in his article (2016) the problems of describing the Krasnoyarsk's architecture, posed back in the late 1950s by an outstanding Siberian researcher specialising in architecture - Evgenii Andreevich Ashchepkov (1907-1983). The article analyzes draft notes for his book in which he gave a professional assessment of the planned and spatial structure of the city, its historical and cultural heritage, modern architecture, developed a system of monographic presentation of the essence of the existing urban environment, the Krasnoyarsk's place and role in the Siberian whole.

Researchers of the Krasnoyarsk urban space and its historical architecture show that the historical architectural heritage is reconceived and becomes the creative basis for modern social and cultural projects. Innovative approaches in the design of restaurant and hotel complexes are based on the renovation of Krasnoyarsk historical places in accordance with the draft from the article by G.V. Ivanova and O.Ia. Kol'man (2016). The project is intended to mean the restoration of the historic quarter for future creation of a new restaurant and hotel complex.

The article by art historians A.I. Fil'ko and A.V. Kistova (2016) is devoted to one of the bright works of Krasnoyarsk architecture in the late $19^{\text {th }}$ century - P.I. Gadalov's mansion, where the Krasnoyarsk Surikov Art Museum is located now. The authors analyze the construction using typological, philosophical and art history methods and think it necessary to embody the revealed meanings in the urban and socio-cultural environment implementing the "Museum Quarter" project.

Moreover, Krasnoyarsk cultural experts carried out a series of studies in the aesthetics of Krasnoyarsk streets and buildings. The results can be found in the articles by M.A. Kolesnik, M.M. Mirkes (2011); M.M. Mirkes, N.A. Sergeeva (2011); M.V. Tarasova, T.Iu Grigor'eva, (2011); N.N. Pimenova, A.V. Marysheva (2011); in the collective monographs "The new future for Siberia: expectations, challenges, solutions" (Bukharov et al., 2013), "New art criticism on the Yenisei Banks" (Bralkova et al., 2015). 
Thus, research in the field of preserving the historical and cultural city identity implies identifying possibilities of harmonization and offers specific projects for modernization and innovation in the city architectural space, nevertheless, only some authors regard the natural conditions of the city's location as a starting point. The idea of a garden city, which is stipulated by the city's ecological situation, faces various obstacles related to economic mechanisms and transformations of the country's social life. The thorny problems of particular buildings and streets are studied in detail, and since these problems are typical their solution inspires similar projects.

3. Social and cultural aspects of creating the Krasnoyarsk urban environment

The socio-cultural relation reflects the attitude of city residents to their own habitat, the problem of perception and the formation of urban identity. Such studies are conducted on the basis of citizens' monitoring.

An article by N.P. Koptseva, Iu.S. Zamaraeva, A.V. Kistova, N.N. Pimenova, N.N. Seredkina, K.V. Reznikova, A.I. Fil'ko (2016) deals with visual encoding and decoding of urban space, while A.V. Kistova, M.V. Moskalyuk, E.A. Sertakova, A.P. Dvoretskaia (2016) promote the significance of the great Russian artist Vasily Ivanovich Surikov for Krasnoyarsk.

In the process of research in 2018 A.I. Fil'ko (Fil'ko, 2018) interviewed 187 people. The main areas for the survey were Krasnoyarsk Economic Forum, Krasnoyarsk Cosplay Convention “AVector”, Siberian Federal University, Krasnoyarsk Book Culture Fair. Tourists from other cities that sometimes visit Krasnoyarsk and passengers of trains arriving in the city were interviewed, too. An online questionnaire was also launched. Such a choice of these sites was made not only because of a large number of people in these places (foot traffic), but also due to a high probability of interaction with tourists. When analyzing the data, it was established that the most substantial contribution to the symbolic space of the Krasnoyarsk centre was made by natural objects. In the above mentioned study, such an object turned out to be the Yenisei River and also such constituents of the city as the embankment and the bridge. The centre of Krasnoyarsk has a very clear visual image, the conveyors of which are rivers, bridges and embankments.

The civilizational orientations among the population of Krasnoyarsk Krai (region) and cultural level of the Krasnoyarsk citizens were thoroughly studied by M.I. Il'beikina (2011), N.P. Koptseva, Iu.S. Zamaraeva, E.A. Sertakova (2011). Besides, the social moods of young Krasnoyarsk residents were investigated by various researchers, for instance, O.V Vasil'eva (2015), Iu.N. Moskvich, A.G. Feklistov (2014). 
V.I. Zlotkovskii (Zlotkovskii, 2014) inquired into the dynamics of the social wellbeing and political orientations of the Krasnoyarsk student youth (2006-2013); the author had to acknowledge a decline in public attitude in connection with the idea that the urban environment has changed for the worse. In the 2013survey 903 students from six Krasnoyarsk universities participated, and in comparison with the results of earlier polls, they expressed more pessimism about the city's future in 2013. While in 2006 the first place in the range of city problems identified by students belonged to low salary and wages, in 2013 the main bottleneck was the problem of traffic jams. This deterioration in social well-being and general feeling about it has led to an increase in the migration of educated youth to other cities and countries. Some of the factors admitted in Krushlinsky article's (2016) also coincide to some extent with the problems identified by the youth. These are insufficient number of landscaping objects for urban greening, a lack of other well-equipped recreational territories of high quality; prevalence of lowquality housing stock; disadvantages of the transport system, namely a large amount of traffic jams and an increase in the number of territories occupied by parking lots; high level of air pollution, migration problems.

The impact of migration to Krasnoyarsk Krai from the 1950s to the 1980s on the formation of urban population is evaluated by N.V. Gonina (2016). According to her, the influx of migrants in these years was the largest in the country. She believes that migration has become a source of urban population stratum creation and defined the city's social environment. It was the constant social movement that allowed the capital of Krasnoyarsk Krai to develop steadily.

In connection with the same migration issue, I.Yu. Kudinova (2012) argues that making creative industries will lead to the desired reduction in the migration of educated youth to other regions and countries. Meanwhile, city's brand and image, which may make it attractive and original, interesting for tourists and something to be proud of for locals, is of no small importance for the urban environment. The author has not found any positive image of the city in V.P. Astafyev's books, where the city is opposed to the village and at the same time appears as a habitat for exiles. The same gloomy image of the city as a stifling place, cramped and indifferent to a common person abode, is also given by another famous writer - E. Rusakov. However, V.P. Astafyev highly appreciated the natural beauty of the place chosen by the city's founder Andrei Dubensky to erect the fortress. Therefore, perhaps, first of all, it is necessary to preserve the emotional connection of citizens with the natural context of the city - with the Yenisei waves, blue taiga, red mountains, green poplars. 
The problem of migration in and out of the city is studied by such researchers as N.P. Koptseva, G.S. Soshina, D.S. Shestopalova (2016). The authors present the results of a local exploration into the causes and accompanying circumstances of labour migration in Krasnoyarsk. The study was conducted in October-November 2015. The main method of research was the questionnaire instrument. Theoretical bases for the research were the concepts "acculturation", "inculturation", "acculturation shock", developed in the works of the famous Canadian and American sociologist J. Berry. Having used the theoretical approach of J. Berry and their own empirical study, the researchers have drawn conclusions about the specifics of migration processes in Krasnoyarsk, in particular, it turned out that migrant workers come more often with their families, which decreases the intensity of cultural shock for them. Obviously, young people find it easier to adapt to another cultural society. Respondents noted some difficulties in adapting to the Russian environment, but in general they did not accuse this process of being onerous. It is important that the majority of the respondents were aware of the institutes to which they would apply, if their rights were violated or ignored.

Furthermore the city should adapt for all its inhabitants. The team of the Krasnoyarsk scientists - N.P. Koptseva, Iu.S. Zamaraeva, E.A. Sertakova (2011) organized monitoring and made an analysis of contemporary cultural needs of people with disabilities. The problem of lack of leisure facilities for such a category of people and their isolated way of life account for negative social well-being of the city's population. The project "My City, My Home, My Family", proposed by the authors on the basis of their research, would contribute to the recreation of the city as a place of social prosperity and flourishing.

Krasnoyarsk also became the object for a monographic study of socio-cultural space by the aforesaid authors - E.A. Sertakova, N.P. Koptseva (2015), and then a number of scientific articles on the specific problems in Krasnoyarsk Kari followed (see: Sertakova, Zamaraeva, Sitnikova, 2015; Koptseva et al., 2016; Zamaraeva, 2018, etc.)

Many researchers were engaged in projects related to improving the urban environment comfort via improving the road conditions in Krasnoyarsk. This factor is also a socio-cultural aspect, since it is the road that creates convenience for all categories of citizens, making them more mobile. So, E.A. Vagner in her article (2013) analyzes the pedestrian environment of Krasnoyarsk, which is indispensible for the sustainable development of a large city and contributes to the individual mobility of a 
city resident, and, consequently, enhances the comfort of the urban environment. She paid particular attention to the space for bicycles and pedestrians. In addition to the pedestrian area of Krasnoyarsk, the subject of her research is the zoning of parking spaces in Krasnoyarsk as a city with high density residential development. The multilevel parking project was proposed by the youth researchers of SFU (Mikhailova, Zhavner, Kulakovskaa, 2016).

In the article by A.D. Miakota (2016) one can find the architectural and urban planning credo, views and practical experience of architects who are to implement the concept of better social and recreational environment of Krasnoyarsk, which can be fully realized only with the collaboration of government, business, architects and urban communities. The author deduces that the emergence of a high quality urban environment is possible only taking into account the interests of different social groups, communities and each city's resident, united in complex, in conjunction with objectively occurring in the city processes and its architectural and spatial amenities.

Characterizing the bright natural and ecological skeleton of Krasnoyarsk, A.D. Miakota reports that it comprises island and riverine areas (located in the centre Island Otdykha (which in Russian means "recreation") with sports infrastructure and Tatyshev Island, preserved by the public and the city administration as an undeveloped natural space), spurs of the Sayan Mountains with nature reserve Stolby ("Rock Pillars", one of the most popular historical places for recreation of Krasnoyarsk residents in the countryside), Bobrovy Log ("Beavers' Ravine", a ski resort in the city with its pistes going down to the river Bazaikha flowing in the canyon of Torgashinsky ridge). These locations are on the right bank of the river Yenisei, while on the left bank there are Nikolaevskaya hill (with a complex of specially designed ramps for ski jumping, biathlon academy and winter sports academy) and others. The author draws attention to the fact that the construction of the hydropower plant has changed the dialogue of residents with the Yenisey River, which in 1961 stopped to freeze in winter and in summer now its temperature does not go above 14 degrees Celsius. According to the author's remark, "today the river is regarded by the citizens as something separate, inaccessible and cold. According to polls, $80 \%$ of Krasnoyarsk residents said they do not interact with the river in any way, except for travelling through bridges to the other bank". On the other hand, the author in connection with the ice-free Yenisei offers to plan the development of river transport, which would compensate for this lack of citizens' communication with the Yenisei. 
A.D. Miakota mentions the problem of deforestation for the construction of Krasnoyarsk, and also highlights the construction of high-rise buildings on the banks of the Yenisei, which hinder the flow of fresh air.

E.V. Avdeeva, V.F. Poletaikin,E.A. Vagner(2015), E.V. Avdeeva, V.F. Nadem'ianov, N.V. Masliuk (2013) assess the quality of green lawns in Krasnoyarsk. Green lawns have a healing effect, they are aesthetic, decorative, ecological, dramatically improve the quality of the urban environment. The formation of a lawn belt is an effective way to purify the air, prevent sediment detachment, soil spraying and erosion. In the article the technique of estimating the quality of lawn grass was also considered. Influence of microclimatic conditions and technogenic impact of Krasnoyarsk on the growth and development of lawn grass layer was studied. An analysis of the humidification conditions of Krasnoyarsk in relation to the layout and maintenance of lawns shows that, in general, the city's location guarantees sufficient precipitation for normal growth and development of lawn grasses, except for May and September, but periodically in this climatic zone there are extremely drought conditions for the growth and development of lawn grasses; often the plants on the lawns are subjected to excessive moisture due to a large amount of precipitation (fall occurs in short intervals); on top of all that precipitation is distributed unevenly. Periods with a large amount of precipitation alternate with periods of relative drought. Estimation of the quality of the lawn grass is a difficult task, it depends on the type of lawn, season, subjective features, purposes for which lawns will be used. The researchers evaluated public lawns according to the following indicators: projective coverage, composition (species of grass and plants), engineering and technical condition of territories, anthropogenic stability. The main qualitative and quantitative characteristics were obtained in the course of the inspection of the Krasnoyarsk lawns. The main causes of the degradation of lawns in the urban environment were identified with specifying the places of increased risk for the growth and development of lawn grass varieties.

Also greening of Krasnoyarsk is analyzed in the articles by E.V. Avdeeva, E.A. Selenina (2018), E.V. Avdeeva, E.A. Vagner, V.F. Nadem'ianov, N.V. Shmarin (2016), where the city's public gardens of Krasnoyarsk and their role in the city greening are examined. The researchers paid especial attention to the health of the citizens (Averchenko, 2013) and the economic development of the city (Popod'ko, 2016).

In general, the problems of the urban environment in the social plan of Krasnoyarsk have been scrupulously studied, the attitude of Krasnoyarsk citizens and migrants to these problems has been revealed. The researchers have discovered a positive trend 
that is a vital aspect of the urban environment security. Also scientific articles cover cultural and leisure impediments of low-mobility citizens. Definitely, social, cultural, aesthetic and ecological factors interact closely as regards city greening. The existing practices in the field of research of social and cultural well-being of citizens can be used for studies of psychological and emotional attachment to the city of its inhabitants.

\section{Conclusion}

Problems listed in the present review as the main ones are very wide in scope, they cover a large number of secondary questions, and besides, they are closely connected, so, in studies they are often interchanged or mixed. It should be stated that ecological deterioration influences the perception of the city one lives in and forms the city's image as a cramped, uncomfortable place which one should leave, wants to go away from it forever. Urban high rise development is conditioned not only by the change of style, but also by the contact with nature, though this fact is often neglected (e.g., when the building is erected without any possibility of good aerating, lighting or greening). Therefore the concept of the garden city in studies devoted to Krasnoyarsk building plan shall synthesize all three directions - ecological, aesthetic, social and cultural.

The researchers of the Krasnoyarsk's urban environment have no heated disputes on the matter, since each study is based on its own method and approach and brings its own details into the overall mosaic picture. However, the main tendency of studies of the Krasnoyarsk's urban environment is the search for a harmonic measure, a point of balance in which there could be interaction of the natural-ecological and socio-cultural grounds. The researchers are primarily concerned with mapping and cataloging the most successful points of such interaction, exploring the natural possibilities and assessing the urgent problems of the urban environment. A large number of studies on the architectural heritage of Krasnoyarsk attests to a recent trend of strengthening a positive urban identity and the dissemination of ideas for preserving the traditional city's look in modern conditions. The historical value of old city's buildings is becoming more evident due to existing projects and plans for their preservation. What is more, it is essential to study the attitude of citizens to the Krasnoyarsk's key objects, which make up a naturalecological or historical-cultural structure of the city. The systematic monitoring of public opinion seems promising in the future, both for observing the dynamics of changes and for increasing the civic consciousness and activity of city residents against these changes. In the long run, the scientists who study the city have to work out a unified concept of further purposeful activity that would prevent the entropic flow. 


\section{References}

Antonenko, O.V. (2013). Istoriko-geograficheskie aspekty gradostroitel'stva na territorii starorusskikh gorodov Sibiri (na primere g. Krasnoiarska) [Historical and geographical aspects of urban development in old Russian cities of Siberia (on the example of Krasnoyarsk)]. In Vestnik KGPU im. V.P. Astaf'eva [Bulletin of Krasnoyarsk State University named after V.P. Astafyev], 3(25), 260-265.

Avdeeva, E.V., Karelina, A.A. (2017). Tekhnogennye izmeneniia reki Enisei pod vozdeistviem faktorov gorodskoi sredy krupnogo promyshlennogo tsentra (na primere g. Krasnoiarska i ego okrestnostei): ekologiia i ratsional'noe prirodopol'zovanie [Technogenic changes in the Yenisei River under the influence of urban environment factors of a large industrial centr e (on the example of Krasnoyarsk and its surroundings): ecology and rational nature management]. In Materialy Vserossiiskoi nauchno-prakticheskoi konferentsii [Materials of the scientific-practical conference], 5-7, Yaroslavl.

Avdeeva, E.V., Nademyanov, V.F. (2013). Otsenka sostoianiia gorodskoi sredy metodami dendroindikatsii [The assessment of urban environment condition by dendroindication methods]. In Vestnik KrasGAU [Bulletin of KrasSAU], 11, 199-205.

Avdeeva, E.V., Nademyanov, V.F., Maslyuk, N.V. (2013). Otsenka kachestva zelenykh nasazhdenii (na primere gazonov obshchego pol'zovaniya g. Krasnoiarska) [The quality assessment of urban greening (on the example of grass lawns in Krasnoyarsk)]. In Sistemy. Metody. Tekhnologii [Systems. Methods. Technologies], 3 (19), 196-201.

Avdeeva, E.V., Poletaikin, V.F., Vagner, E.A. (2015). Istoricheskie aspekty vzaimosviazi prirodnogo okruzheniya, kompozitsionnoi struktury i sistemy ozeleneniya goroda Krasnoiarska [Historical aspects of interrelation between natural environment, composition, structure and systems of urban greening]. In Sovremennye problemy nauki i obrazovaniia [Modern issues of science and education], 2-2, 830.

Avdeeva, E.V., Selenina, E.A. (2018). Programma razvitia sistemy kompleksnogo ozeleneniya i blagoustrojstva territorii goroda Krasnoiarska [Development program for the system of comprehensive urban greening and capital improvement in Krasnoyarsk], In Khvoinye boreal'noi zony [Coniferous trees in boreal area], 34(1), 38-44.

Avdeeva, E.V., Vagner, E.A., Nademyanov, V.F., \& Shmarin, N.V. (2016). Gorodskie skvery - ikh rol' v ozelenenii gorodov (na primere istoricheskogo razvitiia, obespechennosti i sostoianiia skverov g. Krasnoiarska) [City mini-parks - their role in city urban greening [on the example of historic development, state and availability of 
mini-parks in Krasnoyarsk], In Khvoinye boreal'noj zony [Coniferous trees in boreal area], 34(1-2), 7-15.

Averchenko, E.A. (2013). Okhrana zdorov'ia naseleniia na regional'nom i munitsipal'nom urovniakh [Public health protection at the regional and municipal levels]. In Sotsial'nye aspekty zdorov'ia naseleniia [Social aspects of public health], 29 (1), 5.

Bobylev, S.N., Kudriavtseva, O.V., \& Solov'eva, S.V. (2014). Indikatory ustoichivogo razvitiia dlia gorodov [Sustainable development indicators for cities]. In Ekonomika regiona [The regional economy], 3, 101-110.

Bralkova, A.V., Gerasimova, A.A., Govoruhina, Iu.A., Grigor'eva, T.Iu., Gur'ianova, V.A., Zhukovskii, V.I., Karlova, O.A., Kistova, A.V., Kolesnik, M.A., Koptseva, N.P., Kushnareva, A.V., Lebedeva, T.V., Lomanova, T.M., Marysheva, A.V., Mirkes, M.M., Moskaliuk, M.V., Pimenova, N.N., Reznikova, K.V., Saimova, V.S., Sergeeva, N.A. (2015). Novaia art-kritika na beregakh Eniseia [New art criticism on the banks of the Yenisei River]. Krasnoyarsk, Siberian Federal university, 338 p.

Bukharov, A.V., Bakhova, N.A., Viktoruk, E.A., Viktoruk, E.N., Grigor'eva, T.Iu., Zamaraeva, Iu.S., Il’beikina, M.I., Karlova, O.A., Keush, A.V., Kirko, V.I., Kistova, A.V., Komaritsyn, S.G., Koptseva, N.P., Kuimov, V.V., Kushnareva, A.V., Moskvich, Iu.N., Nevzorov, V.N., Nevol'ko, N.N., Nozdrenko, E.A., Pavlov, P.A. (2013). Novoe budushchee Sibiri: ozhidaniia, vyzovy, resheniia [The new future of Siberia: expectations, challenges, solutions]. Krasnoyarsk, Siberian Federal university, 490 p.

Bukova, M.I. (2017). Vizual'naia antropologiia i social'noe konstruirovanie [Visual anthropology and social engineering]. In Sibirskii antropologicheskii zhurnal [Siberian anthropological journal], 2, 6-23.

Chernykh, E.P., Pervyshina, G.G., Gogoleva, O.V. (2014). Otsenka ekologicheskogo blagopoluchiia territorii g. Krasnoiarska s ispol'zovaniem cheremukhi obyknovennoi v kachestve bioindikatora [The assessment of ecological well-being of Krasnoyarsk with the bird cherry used as a bioindicator]. In Vestnik KrasGAU [Bulletin of KrasSAU], 1, 96-100.

Danileiko, V.A. (2013). Government institutions and scientific organizations and their role in the ethnographic study of the north of Siberia in 1920-1930-s. In Journal of Siberian Federal University. Humanities \& Social Sciences, 6 (6), 798-815.

Dontsov, A.S., Suntsova, L.N., Inshakov, E.M. (2016). Otsenka sostoianiia okruzhaiushchei sredy g. Krasnoiarska po sostoyaniiu fotosinteticheskogo apparata eli sibirskoi [Assessment of the environment state in Krasnoyarsk through the use of the photosynthetic apparatus of Siberian spruce], In Khvoinye boreal'noi zony [Coniferous trees in boreal area], 37 (5-6), 246-250. 
Dvinsky, M.B., Rutskii, V.N., Pochekutova, E.N., Bulavchuk, A.M. (2016). The socio-economic effectiveness of funding for the motor roads network skeleton formation in the region. In Journal of Siberian Federal University. Humanities \& Social Sciences, 9 (8), 1916-1928.

Dvinsky, M.B., Drobyshev, I.A., Nepomnyaschaya, N.V., Pavluchenko, T.V. (2017). Smart city: "smart" infrastructure, networks and communications. In Journal of Siberian Federal University. Humanities \& Social Sciences, 10 (12), 1869-1875.

Fil'ko, A.I. (2018). Osobennosti vospriiatiia vizual'nogo obraza Krasnoiarska zhiteliami i gostiami goroda: metod dekodirovaniia [Features of perception of the Krasnoyarsk's visual image by citizens and guests of the city: the method of decoding]. In Spetsifika etnicheskikh migratsionnykh protsessov na territorii Tsentral'noi Sibiri $\checkmark$ XX-XXI vekakh: opyt i perspektivy [Specificity of ethnic migration processes on the territory of Central Siberia in the $20^{\text {th }}-21^{\text {st }}$ centuries: experience and prospects]. 138143. Krasnoyarsk.

Fil'ko, A.I., Kistova, A.V. (2016). Usad'ba P.I. Gadalova v gorode Krasnoiarske kak ob'ekt kul'turnogo naslediia regional'nogo znacheni'a [The P.I. Gadalov's mansion in Krasnoyarsk as an object of cultural heritage of regional importance], In Urbanistika [Urbanistics], 4, 1-26.

Golubnichii,A.A.,Chaikina,E.A.(2015). Posezonnyeizmeneniia srednesutochnykh znachenii kontsentratsii monooksida ugleroda v g. Krasnoiarske za odnoletnii period [Seasonal changes of daily average CO concentration in Krasnoyarsk per 1 year], In Naukovedenie [Science Studies], 7 (3), (28), 98.

Gonina, N.V. (2016). Vliianie migratsionnykh protsessov na formirovanie gorodskogo naseleniia v Krasnoiarskom krae vo vtoroi polovine 1950-kh - nachale 1980-kh gg, [Migration processes influence on forming the urban population in Krasnoyarsk Krai from the second half of the 1950-s to the beginning of the 1980s], In Vestnik Kemerovskogo gosudarstvennogo universiteta [Bulletin of Krasnoyarsk State University], 4 (68), 28-34.

Grekov, N.I. (2014). O sokhranenii zhilykh kvartalov predvoennykh i pervykh poslevoennykh let postroiki v Krasnoiarske [On preservation of pre-war and the first post-war inhabited quarters in Krasnoyarsk], In Balandinskie chteniya [Balandin Readings], 9 (3), 209-214. Novosibirsk.

Il'beikina, M.I. (2011). Civilizational orientation of the population of the united Krasnoyarsk Krai: 15 to 60 years of age residents of Krasnoyarsk city, In Journal of Siberian Federal University. Humanities \& Social Sciences, 4 (6), 846-864. 
Il’beikina, M.I., Kolesnik, M.A., Libakova, N.M., Sertakova, E.A., \& Sitnikova, A.A. (2015). Global and local trends in development of the Siberian city of Krasnoyarsk, In Mediterranean Journal of Social Sciences, 6, 3, 241-248.

Ivanova, G.V., Kol'man, O.Ia. (2016). Innovatsionnye podkhody v proektirovanii restoranno-gostinichnykh kompleksov: renovatsiia istoricheskikh mest g. Krasnoyarska [Innovative approaches in the design of hotel-resort complexes: renovation of historic places in Krasnoyarsk], In Sovremennaia nauka i innovatsii [Modern Science and Innovations], 4 (16), 12-16. North-Caucasus Federal University, Stavropol.

Kistova, A.V. (2017). Integratsiia ehtnograficheskogo podkhoda $i$ "ponimaiushchei germenevtiki" kak metodologicheskaia strategiia konstruirovaniia sotsial'nykh identichnostei [Integration of the ethnographic approach and "understanding hermeneutics approach" as a methodological strategy for constructing social identities], In Sibirskii antropologicheskii zhurnal [Siberian anthropological journal], 2, 24-40.

Kistova, A.V., Moskalyuk, M.V., Sertakova, E.A., Dvoretskaya, A.P. (2016). Ispol'zovanie imeni Vasiliia Ivanovicha Surikova v konstruirovanii polozhitel'nogo obraza goroda Krasnoyarska [Using the name of Vasily Ivanovich Surikov in constructing a positive image of Krasnoyarsk], In NB: Administrativnoe pravo i praktika administrirovaniia [NB: Administrative Law and Administrative Practice], 6, 1-13. DOI: 10.7256/2306-9945.2016.6.20967. Available at: http://e-notabene.ru/al/article_20967.html

Kolesnik, M.A., Mirkes, M.M. (2011). Principles of symmetry in the Krasnoyarsk city space and processes of the regional identity. In Journal of Siberian Federal University. Humanities \& Social Sciences, 4 (12), 1727-1742.

Koptseva N.P., Zamaraeva, Iu.S., Kistova, A.V., Pimenova, N.N., Seredkina, N.N., Reznikova, K.V., Fil'ko, A. (2016). Place management: decoding the visual image of a Siberian city. In Journal of Applied Economic Sciences, 11, 6, 1144-1156.

Koptseva, N.P., Bakhova, N.A. Zamaraeva, Iu.S. (2012). Socio-Cultural Study of Leisure Needs and Preferences of People with Disabilities Living in the City of Krasnoyarsk. In Journal of Siberian Federal University. Humanities \& Social Sciences, 3 (5), 307-323.

Koptseva, N.P., Soshina, G.S., Shestopalova, D.S. (2016). Local Study of the Causes of Labor Migration in the City of Krasnoyarsk (October-November 2015). In Journal of Siberian Federal University. Humanities \& Social Sciences, 4 (9), 824-836.

Koptseva, N.P., Zamaraeva, Iu.S., Sertakova, E.A. (2011). Sociocultural research of the cultural requirements of the residents of the Krasnoyarsk city. In Journal of Siberian Federal University. Humanities \& Social Sciences, 4 (11), 1577-1588. 
Koptseva, N.P., Libakova, N.M., Sertakova, E.A., Luzan, V.S., Kolesnik, M.A., Sergeeva, N. (2016). Brand-management of Siberian Cities (Krasnoyarsk as a case study), In International Review of Management and Marketing, 6, S5, $185-191$.

Krushlinskii, V.I. (2016). Problemy vzaimodeistviia prirodnykh i gradostroitel'nykh system [Problems of interaction between natural and urban planning systems]. In Mozaika gorodskikh prostranstv: ekonomicheskie, sotsial'nye, kul'turnye $i$ ekologicheskie protsessy [Mosaic of urban spaces: economic, social, cultural and ecological processes], 217-222. Moscow.

Krushlinskii, V.I., Fedorova, O.S. (2016). Considering aesthetic characteristics in the master plan of Krasnoyarsk. In Journal of Siberian Federal University. Humanities and Social science, Krasnoyarsk, 9(8), 1880-1887.

Krushlinskii, V.I. (2013). Antikrizisnyi genplan, problem i perspektivy (na primere g. Krasnoiarska) [Anti-crisis city master plan, problems and prospects (on the example of Krasnoyarsk]. In Polzunovskiivestnik [Polzunovsky Herald], 4-1, 110-114.

Kudinova, I.Iu. (2012). Sibirskii gorod v khudozhestvennoi literature [A Siberian city in fiction], In Diskussiia [Discussion], 6, 21-26.

Mikhailova, M.A., Zhavner, T.V., Kulakovskaia, V.V.(2016). Problemyobespecheniia naseleniia parkovochnymi mestami v usloviiakh slozhivsheisia i stesnennoi gorodskoi zastroiki [Problems of provision with parking lots under conditions of the current restricted urban development areas]. In Sovremennaia nauka i innovatsii [Modern Science and Innovations], 4 (16), 12-16.

Mirkes, M.M., Sergeeva, N.A. (2011). Codification of the cultural meanings of the Krasnoyarsk street ornaments. In Journal of Siberian Federal University. Humanities \& Social Sciences, 4 (12), 1794-1806.

Moskvich, Iu.N., Feklistov, A.G. (2014). Humanist Students' Values of Progressive Development: Comparative Study. In Journal of Siberian Federal University. Humanities \& Social Sciences, 7 (12), 2042-2048.

Miakota, A.D. (2016). Dialog s Eniseem. Kontseptsiia renovatsii i obustroistva pribrezhno-ostrovnogo rekreatsionnogo karkasa Krasnoiarska [A dialog with the Yenisei. Renovation concept and development plan of riverine and island structure in Krasnoyarsk]. In Proekt Baikal [The Baikal Project],13 (50), 106-111.

Petrov, K.G. (2012). Discussions about the big Krasnoyarsk city planning design in the 1930s. In Journal of Siberian Federal University. Humanities \& Social Sciences, $5(5), 685-690$. 
Pimenova, N.N., Marysheva, A.V. (2011). Wooden zodchestvo of Krasnoyarsk city as the space for forming territorial and ethno-cultural identity. In Journal of Siberian Federal University. Humanities \& Social Sciences, 4 (12), 1784-1793.

Poletaikin, V.F., Avdeeva, E.V., Vagner, E.A. (2015). K otsenke kachestva gorodskikh ob'ektov ozeleneniia [On assessing the quality of urban greening objects]. In Ekologiia $i$ bezopasnost'v tekhnosfere: sovremennye problem i puti resheniia: Sbornik trudov Vserossiiskoi nauchno-prakticheskoi konferentsii molodykh uchenykh, aspirantov $i$ studentov [Ecology and safety in the tech sphere: current problems and solutions. Collection of works of the All-Russian Scientific and Practical Conference of young scientists, post-graduate students and students], (2), 74-76.

Polishchuk, V.I. (2016). Krasnoyarsk agglomeration: idea and prospects of development. In Journal of Siberian Federal University. Humanities \& Social Sciences, 9 (11), 2803-2829.

Polonskii, V.I., Poliakova, I. S. (2014). Siren’ vengerskaia - perspektivnyi bioindikator dlia sravnitel'noi otsenki stepeni zagriazneniia gorodskoi sredy [Hungarian Lilac - a promising bioindicator for comparative assessment of the urban environment pollution degree]. In Vestnik KrasGAU [Bulletin ofKrasSAU], 2, 89-92.

Popod'ko, G.I. (2016). Long-term strategy for socio-economic development of the city of Krasnoyarsk. In Journal of Siberian Federal University. Humanities \& Social Sciences, 9 (11), 2786-2791.

Sertakova, E.A. (2018). Filosofskie osnovaniia sovremennoi urbanisticheskoi antropologii [Philosophical foundations of modern urban anthropology]. In Sibirskii antropologicheskii zhurnal [Siberian anthropological journal], 2, 2, 70-86.

Sertakova, E.A., Koptseva, N.P. (2015). Sotsiokul'turnoe prostranstvo sovremennogo rossiiskogo goroda (na material analiza goroda Krasnoiarska): monografiia [Socio-cultural space of modern Russian city (on the basis of Krasnoyarsk analysis): a monograph], Krasnoyarsk, 128 p.

Sertakova, E.A., Zamaraeva, Iu.S., Sitnikova, A.A. (2015). Sotsiologicheskoe issledovanie kul'turnykh potrebnostei zhitelei goroda Krasnoiarska [Sociological study of Krasnoyarsk citizens' cultural needs]. In Urbanistika [Urbanistics], 3, 16-42. Available at: http://e-notabene.ru/urb/article_16495.html DOI: 10.7256/23108673.2015.3.16495

Shishatskii, N.G. (2016). Investment potential of structural modernization of the Krasnoyarsk economy. In Journal of Siberian Federal University. Humanities \& Social Sciences, 9 (11), 2792-2802. 
Slabukha, A.V. (2016). E.A. Ashchepkov: "Krasnoyarsk - odin iz znachitel'nykh i interesnykh v arkhitekturnom otnoshenii gorodov Sibiri” (o proekte nenapisannoi knigi) [E.A. Ashchepkov: "Krasnoyarsk - one of the most significant and interesting in architectural terms Siberian cities" (describing the draft of an unwritten book)]. In Balandinskie chteniia [Balandin Readings], Novosibirsk, 11 (1), 225-227.

Suntsova, L.N., Inshakov, E.M., Kozik, E. (2011). Otsenka sostoianiia gorodskoi sredy metodom fitoindikatsii (na primere g. Krasnoyarska) [Assessment of urban environment state by phytoindication method (based on example of Krasnoyarsk)]. In Izvestiia VUZov. Lesnoi zhurnal [News of higher educational institutions. Forest Journal], 4, 29-32.

Tarasova, M.V., Grigorieva, T.Iu. (2011). The architecture of Krasnoyarsk as a space of social identification. Correlation of cosmocentric and sociocentric ideals. In Journal of Siberian Federal University. Humanities \& Social Sciences, 4, (12), 1705-1718.

Taseiko, O.V., Leonova, E.N., Spitsyna, T.P.(2013). Otsenka i analizingaliatsionnogo riska $\mathrm{v}$ regione s neblagopriiatnoi ekologicheskoi obstanovkoi [The assessment and analysisof inhalation risk in the region with the unfavorable ecological conditions]. In VestnikKrasGAU [Newsletter of KrasSAU], 2013, 4, 73-79.

Taseiko, O.V., Mikhailiuta, S.V., Lezhenin, A.A. (2013) Obosnovanie normativov kachestva atmosfernogo vozdukha $\mathrm{v}$ gorode [Validation of regulations on city atmosphere air]. In Ekologiia i promyshlennost'Rossii [Russian ecology and industry], 4, 56-61.

Vagner, E.A. (2013). Mesto velo-peshekhodnykh prostranstv v sisteme mobil'nosti naseleniia krupnoi aglomeratsii (na primere Krasnoyarskoi aglomeratsii) [The place of cycling and pedestrian space in the system of the population mobility in a large agglomeration (on the example of the Krasnoyarsk agglomeration]. In Gradostroitel 'stvo [Urban Development], 3 (25), 69-79. Moscow.

Vasil'eva, O.V. (2015). The integrative approach to the study of the social mood phenomenon from the standpoint of the universum sociology (on the example of the social mood of young people in Krasnoyarsk). In Journal of Siberian Federal University. Humanities \& Social Sciences, 8 (11), 2248-2259.

Yamaletdinov, S.F. (2012). Ensemble of the main square in Krasnoyarsk-26: humanized space of totalitarian architecture. In Journal of Siberian Federal University. Humanities \& Social Sciences, 5 (5), 742-755.

Zamaraeva, Iu.S. (2018). Issledovanie otnosheniia k migrantam v Krasnoiarskom krae (rezul'taty assotsiativnogo eksperimenta po metodike "seriinye tematicheskie assotsiatsii") [Investigation of the attitude towards migrants in Krasnoyarsk Krai 
(the results of an associative experiment through the method of "serial thematic associations")]. In Severnye arkhivy $i$ ekspeditsii [Northern archives and expeditions], 2, 2, 69-80.

Zlotkovskii, V.I. (2014). Analiz sotsial'nogo samochuvstviia studenchestva vuzov g. Krasnoiarska i Krasnoiarskogo kraia [Analysis of social well-being of university students in Krasnoyarsk and Krasnoyarsk Krai]. In Vestnik Sibirskogo iuridicheskogo instituta FSKN Rossii [Bulletin of the Siberian Law Institute of the Russian Federal Drug Control Service], 1 (14), 166-172.

\title{
Обзор исследований по городской среде Красноярска
}

\author{
М.Г. Смолина, Н.П.Копцева, Е.А. Сертакова \\ Сибирский федеральнылй университет \\ Россия, 660041, Красноярск, пр. Свободньй, 79
}

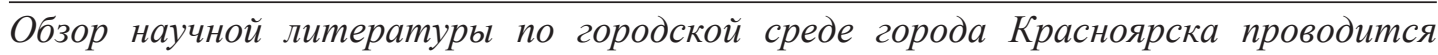
с определением основных направлений исследования данной темы, анализом репрезентативных научных публикаций, отражающих фиксаџию характеристик и динамику изменения среды. Результатом стал анализ свыше 50 источников, включая прикладныле проекты и результать опросов жителей и экспертов. Областью применения результатов статьи является исследование в рамках проекта РФФИ по городским трансформачиям Красноярска с 1990-х по 2010-е г2. В результате определено, что современные исследования Красноярска проходят по следующим направлениям: результаты диагностики по определению уровня экологической благополучности города, мониторинги общественного мнения и исследования причин миграчий образованной молодежи, а также эстетическая критика территории, каталогизация историко-культурного и архитектурного наследия, обсуждения градостроительного плана и проблемы его воплощения, а также проблем всеобщей мобильности горожан, включая доступность городской среды для маломобильных граждан. Более того, в статье обращается внимание на градостроительный замысел «города-сада»как на воплощение синтеза социальных, эстетических и экологических интенций общества.

Ключевые слова: Красноярск, городская среда Красноярска, экология Красноярска, природа Красноярского края, архитектура Красноярска, градостроительство, озеленение Красноярска, дороги Красноярска, молодежь Красноярска, миграция.

Исследование выполнено при финансовой поддержке Российского фонда фундаментальных исследований, Правительства Красноярского края, Красноярского краевого фонда науки в рамках научного проекта «Трансформащия городской среды Красноярска в 1991-2017 22.».

Научная специальность: 24.00.00 - культурология. 